\title{
ZASTOSOWANIE DWUPLASZCZOWEGO WYMIENNIKA CIEPŁA Z WARSTWĄ PCM DO ODZYSKU CIEPŁA ODPADOWEGO
}

\begin{abstract}
W pracy zaprezentowano koncepcję wykorzystania materiału zmiennofazowego PCM (phase change material) w układzie do odzysku ciepła odpadowego. W proponowanym rozwiązaniu zbiornik akumulacyjny jest dwupłaszczowy. Utworzona między płaszczami szczelina cylindryczna jest wypełniona organicznym materiałem zmiennofazowym, który podczas nagrzewania wody w zbiorniku zmienia stan skupienia, akumulując energię cieplną oraz zwiększając pojemność cieplną zbiornika. Omówiono możliwości odzysku ciepła odpadowego, potencjalne zastosowania materiałów PCM w układach mobilnych oraz stacjonarnych, dokonano także charakterystyki przemian fazowych w aspekcie wykorzystania materiału zmiennofazowego do akumulacji ciepła. Przedstawiono główne założenia konstrukcyjne, przeanalizowano możliwości zastosowań wybranych materiałów PCM oraz omówiono korzyści proponowanego rozwiązania.
\end{abstract}

Słowa kluczowe: materiał zmiennofazowy, ciepło odpadowe, akumulacja ciepła

\section{Wprowadzenie}

Wykorzystanie ciepła odpadowego jest obecnie coraz bardziej powszechne, ze względu na wiele czynników warunkujących taką metodę pozyskiwania energii. Są to zarówno czynniki techniczne, ekonomiczne, jak i ekologiczne. Rozwinięte nowoczesne technologie stosowane w urządzeniach energetycznych umożliwiają odzyskiwanie energii $\mathrm{z}$ ciepła odpadowego produkowanego podczas przemian energetycznych zachodzących $w$ tych urządzeniach. Z drugiej strony, względy ekonomiczne przyczyniają się do wzmożonego zainteresowania ciepłem odpadowym, którego wykorzystanie może spowodować duże oszczędności. Ciepło odpadowe może być wykorzystywane nie tylko do generowania energii elektrycznej, ale także do chłodzenia pomieszczeń, zamrażania produktów, suszenia, skraplania gazów itp. Na trzeci aspekt odzysku ciepła odpadowego składają się czynniki ekologiczne. W warunkach środowiska naturalnego wykorzystanie

${ }^{1}$ Autor do korespondencji/corresponding author: Robert Smusz, Politechnika Rzeszowska, 35-959

Rzeszów, al. Powstańców Warszawy 12, tel.: 17 8651242, e-mail: robsmusz@prz.edu.pl

2 Joanna Wilk, Politechnika Rzeszowska, e-mail: joanwilk@prz.edu.pl 
ciepła odpadowego przez przetworzenie go w inną formę energii stanowi jeden ze sposobów poprawy stanu i ochrony środowiska, m.in. dzięki zmniejszeniu niekorzystnych efektów spalania paliw będących głównym źródłem energii. Odzysk ciepła odpadowego może się odbywać na dużą skalę. W tym przypadku do jednostek generujących ciepło odpadowe można zaliczyć różne zakłady przemysłowe (fabryki szkła, spalarnie), a także elektrownie konwencjonalne oraz elektrownie opierające się na odnawialnych źródłach energii. Na mniejszą skalę ciepło odpadowe może być odzyskiwane z urządzeń chłodniczych lub klimatyzacyjnych.

Analizowany w pracy dwupłaszczowy wymiennik ciepła stanowi przykład rozwiązania wykorzystującego ciepło odpadowe z wymienionych wcześniej urządzeń. W wymienniku są zainstalowane trzy wężownice grzewcze: górna, dolna oraz wężownica układu odzysku ciepła odpadowego. Przez górną i dolną wężownicę przepływa wysokotemperaturowy czynnik grzewczy (woda). Wężownica układu odzysku ciepła odpadowego jest wykorzystywana do odbierania ciepła od czynnika chłodniczego z instalacji klimatyzacyjnej. Utworzona między płaszczami zbiornika (wymiennika) szczelina cylindryczna jest wypełniona organicznym materiałem zmiennofazowym, który podczas nagrzewania wody w zbiorniku zmienia stan skupienia, akumulując energię cieplną. Główną zaletą takiego rozwiązania jest trwałe odseparowanie materiału PCM od wody użytkowej wypełniającej zbiornik. Ponadto w szczelinie mogą być umieszczone wióry metaliczne, które stanowią metalowy szkielet $\mathrm{z}$ przestrzeniami wypełnionymi materiałem PCM. Zastosowanie dodatkowego wypełnienia metalicznego zwiększa właściwości przewodzące materiału zmiennofazowego, a tym samym intensyfikuje procesy wymiany ciepła.

Głównym celem pracy było określenie kryteriów dotyczących możliwości zastosowania materiału PCM w proponowanym wymienniku. Jednym z nich jest dobór odpowiedniej geometrii zbiornika zawierającego PCM, co można wyrazić przez współczynnik kształtu. Porównano stosowane formy zbiornika ze względu na współczynnik kształtu. Omówiono również wpływ geometrii pojemnika zawierającego materiał zmiennofazowy na czas jego nagrzewania. Opisano rozpatrywany wymiennik, przedstawiono główne założenia konstrukcyjne, przeanalizowano możliwości zastosowań wybranych materiałów PCM oraz omówiono korzyści proponowanego rozwiązania.

\section{Materiały zmiennofazowe w układach odzysku ciepła odpadowego}

Wykorzystanie ciepła odpadowego z dużych zakładów przemysłowych wiąże się z zastosowaniem tzw. mobilnych akumulatorów ciepła z materiałami zmiennofazowymi PCM (phase change material). Technologia ta polega na ładowaniu ciepłem odpadowym specjalnych zbiorników wypełnionych materiałem PCM oraz przetransportowywaniu ich za pomocą samochodów ciężarowych do 
potencjalnych odbiorców. Końcowymi użytkownikami zakumulowanego za pomocą PCM ciepła odpadowego mogą być przedsiębiorstwa wykorzystujące to ciepło do niskotemperaturowych procesów technologicznych, jak też osoby prywatne do zapewnienia pokrycia zapotrzebowania na ciepło do ogrzewania budynku mieszkalnego. Ważnym wymogiem wykorzystania mobilnego akumulatora ciepła z materiałem PCM jest stosunkowo bliska odległość pomiędzy źródłem ciepła odpadowego a odbiorcą. Transport ciepła przy użyciu akumulatorów nie zawsze może być korzystny, ze względu na uzyskiwane mniejsze moce cieplne. Dzieje się tak w przypadku wykorzystania ciepła odpadowego ze źródeł, takich jak urządzenia chłodnicze lub klimatyzacyjne. W związku z tym istnieje potrzeba akumulacji ciepła oraz jego odzysk bezpośrednio na miejscu. Jedną z podstawowych metod akumulacji ciepła jest zastosowanie zbiorników akumulacyjnych na ciepłą wodę użytkową. W takich przypadkach są stosowane rozwiązania konstrukcyjne zbiorników z umieszczonymi dodatkowymi elementami zawierającymi materiały PCM.

Szczegółowy opis materiałów zmiennofazowych, ich właściwości, aplikacji, toksyczności, metod i technologii akumulacji oraz praktycznych aspektów wykorzystania systemów akumulacji energii zawierają m.in. prace [1-6]. Pierwsze badania nad materiałami zmiennofazowymi zostały zapoczątkowane pod koniec lat 40. [7], ale fundamentalne prace nad wykorzystaniem PCM w systemach akumulacji energii podjęto ponownie podczas kryzysu energetycznego w latach 70 . Wyniki tych prac można znaleźć m.in. w publikacjach $[8,9]$. Badania prowadzone w latach 70. i 80. koncentrowały się głównie na wydajności, określeniu zasad projektowania układów magazynowania energii, charakterze procesów zachodzących $\mathrm{w}$ stanie nieustalonym oraz poszukiwaniu i badaniach nowych materiałów zmiennofazowych.

Materiały zmiennofazowe wykorzystywane w układach akumulacji energii powinny się charakteryzować ściśle określonymi właściwościami, zapewniającymi optymalne warunki magazynowania energii termicznej. W pracach $[10,11]$ przedstawiono wymagania, jakie powinny spełniać materiały zmiennofazowe. Wyniki badań wybranych materiałów PCM w aspekcie ich zastosowań w układach do odzysku ciepła odpadowego zawarto w pracy [12]. Materiały PCM powinny posiadać przede wszystkim dużą wartość utajonego ciepła przemiany fazowej na jednostkę objętości (masy) oraz jak największą wartość ciepła właściwego, tak aby umożliwić zmniejszenie wymiarów zasobników zawierających PCM. Dodatkowo materiały zmiennofazowe powinny wykazywać się niskim stopniem przechłodzenia podczas przemiany fazowej, niewielką zmianą objętości i stabilną oraz stałą wartością temperatury przemiany fazowej, dużą prędkością krystalizacji oraz stabilnością i powtarzalnością procesu krzepnięcia. Kolejną wymaganą właściwością jest wysoka przewodność, która pozwoli na intensyfikację transportu ciepła. Poza tym materiały PCM powinny się charakteryzować niskimi wartościami ciśnienia fazy lotnej, tak aby zminimalizować ryzyko rozszczelnienia pojemników, w których się znajdują oraz zredukować koszty ich 
produkcji. Materiały PCM muszą być stabilne chemicznie, nietoksyczne, niepalne oraz wykazywać niską korozyjność.

\section{Przemiany fazowe jako podstawa wykorzystania materiału PCM do akumulacji ciepła}

Przemianą fazową określa się przejście jednej fazy układu znajdującego się w równowadze w inną fazę. W trakcie przemiany fazowej substancja przyjmuje nowy typ struktury lub też nabywa pewne nowe cechy charakterystyczne dla nowej fazy, niewystępujące przed przemianą. Przemiany fazowe są procesami występującymi powszechnie w otaczającej rzeczywistości. Wynikiem przemiany fazowej jest zawsze skokowa zmiana pewnych właściwości fizycznych ciała. Rozróżnia się przemiany fazowe I oraz II rodzaju. Przemiany fazowe I rodzaju to te, podczas których następuje zmiana stanu skupienia, czyli przejście gazu w ciecz oraz cieczy w ciało stałe. Przemiany te charakteryzuje skokowa zmiana gęstości, a zatem i objętości, oraz skokowa zmiana funkcji termodynamicznych: energii wewnętrznej, energii swobodnej, entalpii i entropii. Takie przemiany są zawsze związane z wydzielaniem lub pochłanianiem pewnej ilości energii w postaci ciepła stanowiącego ciepło utajone przemiany fazowej. W przemianach fazowych drugiego rodzaju gęstość oraz wymienione wcześniej funkcje termodynamiczne zmieniają się w sposób ciągły. Z kolei skokowym zmianom mogą ulegać: pojemność cieplna, współczynnik rozszerzalności temperaturowej, współczynnik ściśliwości itp. Ciepło przemian fazowych drugiego rodzaju jest równe zeru, nie są więc one interesujące $z$ punktu widzenia akumulacji energii. Przemiany fazowe I rodzaju są związane ze zmianą stanu skupienia ciał chemicznie jednorodnych, których zmiana stanu zachodzi przy ustalonym ciśnieniu w ściśle określonej i stałej temperaturze.

Topnienie jest przemianą polegającą na przejściu ciała ze stanu stałego w stan ciekły pod wpływem dostarczonego ciepła. Podczas ogrzewania ciała o budowie krystalicznej następuje początkowo liniowy wzrost jego temperatury. Po osiagnnięciu temperatury przemiany fazowej $T_{t}$ dalsze dostarczanie ciepła nie powoduje wzrostu temperatury. W tym czasie dostarczone ciepło jest zużywane na rozrywanie i rozluźnianie wiązań w sieci krystalicznej ciała stałego. Współistnieją jednocześnie dwie fazy - stała i ciekła. Po całkowitym stopnieniu dalsze dostarczanie ciepła powoduje wzrost temperatury fazy ciekłej. Jeżeli topnienie odbywa się pod stałym ciśnieniem, to powyżej temperatury $T_{t}$ istnieje tylko faza ciekła, a poniżej tej temperatury - faza stała. Temperatura topnienia ciał krystalicznych zależy od ciśnienia zewnętrznego. Jeżeli ciała, krzepnąc, zwiększają swoją objętość, to ze wzrostem ciśnienia zewnętrznego obniża się temperatura topnienia. W przypadku ciał, które krzepnąc, zmniejszają swoją objętość, wzrost ciśnienia powoduje wzrost temperatury topnienia. W zagadnieniach przemian fazowych I rodzaju definiuje się pojęcie ciepła topnienia (entalpia topnienia, ciepło 
utajone). Jest to ilość ciepła, jaką należy dostarczyć masie 1 kg danego ciała znajdującego się w temperaturze topnienia, aby przeszło ono ze stanu stałego w stan ciekły o tej samej temperaturze. Zależność pomiędzy temperaturą topnienia $T_{t}$, ciśnieniem $p$, przy którym zachodzi proces, oraz ciepłem topnienia $r$ wyraża formuła Clausiusa-Clapeyrona:

$$
\frac{d p}{d T}=\frac{r}{T_{t}\left(v^{\prime \prime}-v^{\prime}\right)}
$$

gdzie: $v^{\prime \prime}$ - objętość właściwa cieczy, v' - objętość właściwa ciała stałego.

Stosowane materiały PCM charakteryzują się dużymi wartościami ciepła utajonego. Materiały te mogą absorbować, akumulować oraz uwalniać duże ilości energii $\mathrm{w}$ zakresie temperatur przemiany fazowej. W czasie trwania przemiany fazowej materiały PCM pochłaniają i akumulują duże ilości ciepła od otoczenia.

\section{Koncepcja akumulacyjnego zbiornika ciepłej wody użytkowej z wykorzystaniem materiału PCM}

W rozdziale tym zostanie przedstawiona koncepcja dwupłaszczowego zbiornika ciepłej wody użytkowej z dodatkową wężownicą służącą do odzysku ciepła odpadowego. Utworzona szczelina cylindryczna jest wypełniona organicznym materiałem zmiennofazowym, który podczas nagrzewania wody w zbiorniku zmienia stan skupienia, akumulując energię cieplną. Ponieważ w wyniku zmiany fazy może następować zmiana gęstości, a zatem i objętości materiału PCM, szczelina nie jest całkowicie wypełniona. Pozostała wolna przestrzeń zapewnia kompensację zmian objętości PCM. Zaletą rozwiązania jest trwałe odseparowanie PCM od wody użytkowej. Ze względów technologicznych oba płaszcze zbiornika są wykonane z tego samego materiału. Jest nim stal - dobry przewodnik ciepła, umożliwiający intensywną wymianę ciepła pomiędzy wodą w zbiorniku a materiałem PCM zawartym w szczelinie. W celu minimalizacji strat ciepła do otoczenia płaszcz zewnętrzny zbiornika pokrywa dodatkowo materiał izolacyjny. W szczelinie mogą być umieszczone wióry metaliczne, pianka metaliczna lub ceramiczna o otwartych porach, które ze względu na swą budowę stanowią metalowy szkielet z przestrzeniami wypełnionymi materiałem PCM, pozwalający na intensyfikację transportu ciepła. Taka konstrukcja zwiększa właściwości przewodzące materiału zmiennofazowego oraz przyczynia się do skrócenia czasu ładowania/rozładowania akumulatora. Pianki metaliczne i ceramiczne charakteryzują się dużymi wartościami przewodności oraz dyfuzyjności cieplnej w porównaniu $\mathrm{z}$ parafinami stosowanymi jako PCM. Wybrane dane materiałowe zestawiono w tab. 1. 
Tabela 1. Porównanie właściwości termicznych parafiny z metalicznymi i ceramicznymi materiałami spienionymi

Table 1. Comparison of thermal properties of paraffin with metal and ceramic foam materials

\begin{tabular}{|l|c|c|c|c|}
\hline \multicolumn{1}{|c|}{ Materiał } & $\begin{array}{c}\text { Gęstość } \\
{\left[\mathrm{kg} / \mathrm{m}^{3}\right]}\end{array}$ & $\begin{array}{c}\text { Współczynnik } \\
\text { przewodzenia ciepła } \\
{[\mathrm{W} /(\mathrm{m} \cdot \mathrm{K})]}\end{array}$ & $\begin{array}{c}\text { Pojemność } \\
\text { cieplna } \\
{[\mathrm{J} /(\mathrm{kg} \cdot \mathrm{K})]}\end{array}$ & $\begin{array}{c}\text { Dyfuzyjność } \\
\text { cieplna } \\
{\left[\mathrm{mm}^{2} / \mathrm{s}\right]}\end{array}$ \\
\hline $\begin{array}{l}\text { Parafina } \\
\text { (wosk plastyczny) }\end{array}$ & 909 & 0,29 & 2884 & 0,11 \\
\hline $\mathrm{Al}_{3} \mathrm{O}_{3}$ & 3490 & 25 & 703 & 10,19 \\
\hline Aluminium & 2707 & 204 & 896 & 84,11 \\
\hline Miedź & 8933 & 388 & 385 & 112,82 \\
\hline
\end{tabular}

Jak można zauważyć, dyfuzyjność i przewodność cieplna $\mathrm{Al}_{2} \mathrm{O}_{3}$ jest prawie 100 razy większa niż parafiny. W przypadku pianek metalicznych są to wielkości ok. 1000-krotnie większe, wobec tego zastosowanie ceramicznego lub metalicznego szkieletu wydatnie przyczynia się do poprawy wymiany ciepła podczas akumulacji energii w zasobniku wypełnionym materiałem zmiennofazowym. Kolejnym czynnikiem mającym wpływ na warunki wymiany ciepła jest forma geometryczna pojemnika zawierającego materiał zmiennofazowy (tab. 2.). Podstawowym kryterium jest iloraz powierzchni wymiany ciepła do objętości - tzw. współczynnik kształtu. Zwiększenie współczynnika kształtu intensyfikuje procesy wymiany ciepła przez zwiększenie powierzchni w stosunku do zachowanej stałej objętości. Jak widać w tab. 2., przy zachowaniu jednakowej objętości trzech różnych form pojemnika prostopadłościan o założonych wymiarach boków charakteryzuje się współczynnikiem kształtu prawie dwukrotnie wyższym niż w przypadku kuli.

Tabela 2. Porównanie form geometrycznych pojemników na materiały zmiennofazowe

Table 2. Comparison of geometrical forms of the containers for PCM materials

\begin{tabular}{|l|c|c|c|c|c|c|c|}
\hline $\begin{array}{c}\text { Rodzaj } \\
\text { pojemnika }\end{array}$ & $\begin{array}{c}\text { Obj. } \\
\begin{array}{c}V \\
{\left[\mathrm{dm}^{3}\right]}\end{array}\end{array}$ & $\begin{array}{c}\text { Wysokość } \\
{[\mathrm{cm}]}\end{array}$ & $\begin{array}{c}\text { Szerokośćc } \\
{[\mathrm{cm}]}\end{array}$ & $\begin{array}{c}\text { Grubość } \\
{[\mathrm{cm}]}\end{array}$ & $\begin{array}{c}\text { Promień } \\
{[\mathrm{cm}]}\end{array}$ & $\begin{array}{c}\text { Powierzchnia } \\
\text { wymiany ciepła, } A \\
{\left[\mathrm{~cm}^{2}\right]}\end{array}$ & $\begin{array}{c}\text { Współczyn- } \\
\text { nik kształtu } \\
A / V \\
{\left[\mathrm{~cm}^{-1}\right]}\end{array}$ \\
\hline Kulisty & 1 & - & - & - & 6,20 & 483,6 & 0,48 \\
\hline Cylindryczny & 1 & 30 & - & - & 3,26 & 614 & 0,60 \\
\hline $\begin{array}{l}\text { Prostopadło- } \\
\text { ścienny }\end{array}$ & 1 & 30 & 15 & 2,22 & - & 900 & 0,90 \\
\hline
\end{tabular}

W badanych rozwiązaniach zasobników ciepła/chłodu materiały zmiennofazowe umieszcza się wewnątrz zbiorników w postaci kulistych, owalnych lub cylindrycznych pojemników [13-16]. Takie rozwiązania, w przypadku zastosowania ich do systemów przygotowania ciepłej wody użytkowej, mają podstawową wadę 
wynikającą z potencjalnej możliwości zaburzenia stratyfikacji temperatury w zbiorniku oraz rozszczelnienia pojemników wypełnionych materiałem zmiennofazowym, a tym samym zanieczyszczenia wody.

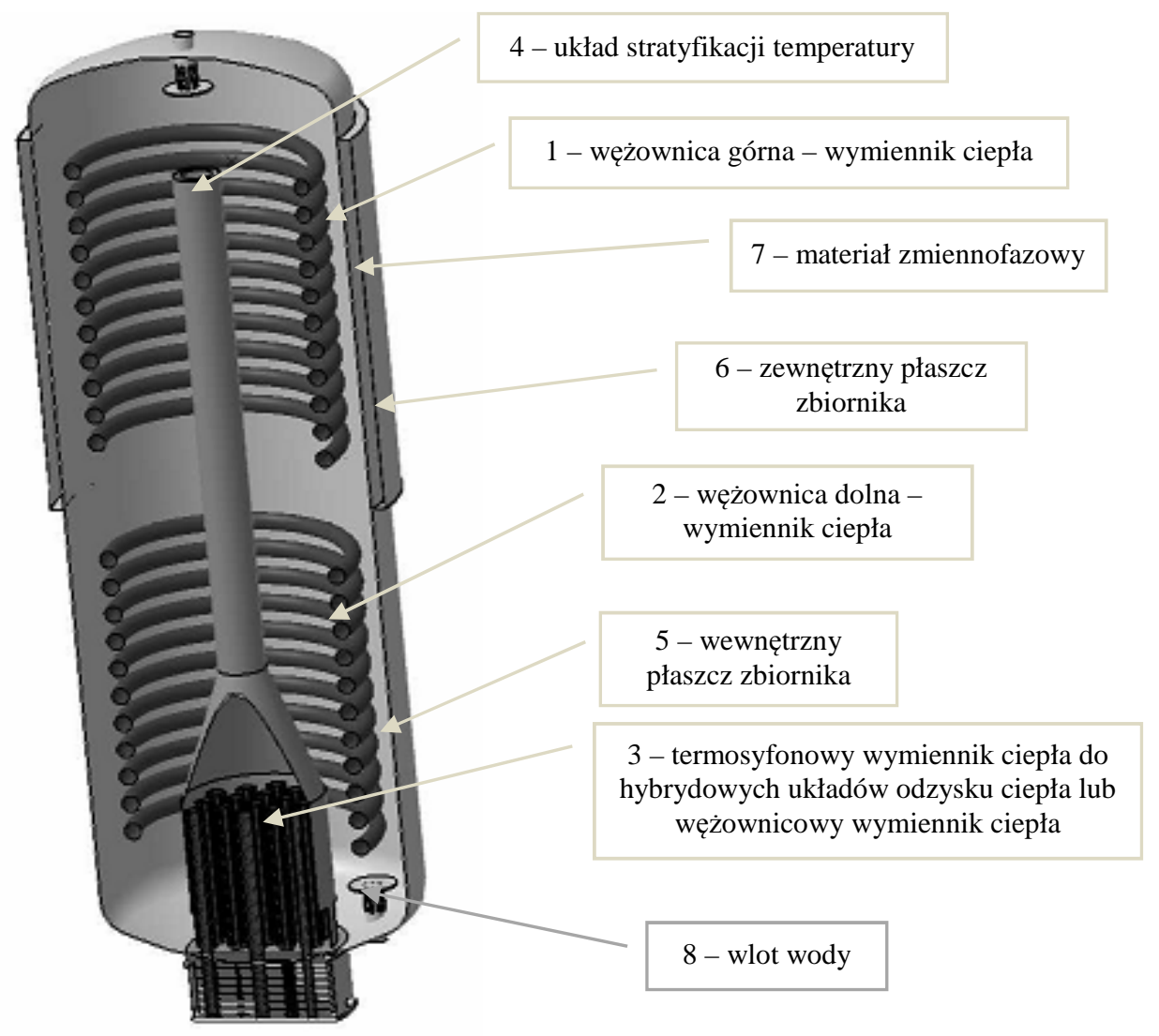

Rys. 1. Schemat zasobnika ciepła z warstwą PCM

Fig. 1. Scheme of a heat accumulator with the PCM cover

Analizowany zbiornik akumulacyjny jest przewidziany do wykorzystania w systemach przygotowania ciepłej wody użytkowej. W zbiorniku wewnętrznym (rys. 1.) są zainstalowane trzy wymienniki ciepła. Wymienniki 1. i 2. są wykonane w formie spiralnej wężownicy. Wymiennik 3. może być wykonany jako wymiennik termosyfonowy lub też w postaci spiralnej wężownicy. Jest on wykorzystywany do odzysku ciepła odpadowego z urządzeń chłodniczych i klimatyzacyjnych [17]. W celu zapewnienia odpowiedniego rozkładu temperatury wody w zbiorniku akumulacyjnym zastosowano układ stratyfikacji 4 [18], wykonany w postaci cylindrycznej rury ze szczelinami rozmieszczonymi na pobocznicy, na różnych wysokościach oraz otworem centralnym w górnej części stratyfikatora. Przestrzeń 
pomiędzy płaszczem wewnętrznym zbiornika 5 a zewnętrznym 6 jest wypełniona materiałem zmiennofazowym 7 , który podczas nagrzewania wody w zbiorniku zmienia stan skupienia ze stałego na ciekły, akumulując energię cieplną oraz zwiększając pojemność cieplną zbiornika. Zasadniczą zaletą przedstawionego rozwiązania jest trwałe odseparowanie materiału zmiennofazowego od wody użytkowej. Pozwala to na zastosowanie dowolnego materiału PCM. Ponadto niewielka grubość przestrzeni, którą wypełnia materiał zmiennofazowy, oraz duża powierzchnia wymiany ciepła pozwalają na szybką penetrację cieplną materiału, w którym zachodzi przemiana fazowa. Ma to istotne znaczenie podczas ładowania/rozładowania zasobnika ciepła - zasadniczo skraca się czas akumulacji ciepła. $\mathrm{W}$ trakcie ładowania zasobnika materiał zmiennofazowy jest $\mathrm{w}$ fazie stałej, co powoduje, że transport ciepła $\mathrm{w}$ głąb materiału odbywa się na drodze przewodzenia. Kluczowym parametrem jest zatem bezwymiarowa liczba Fuoriera Fo, będąca stosunkiem strumienia ciepła transportowanego na drodze przewodzenia do ilości energii termicznej zakumulowanej w materiale. Liczba Fo jest wyrażona w postaci:

$$
\mathrm{Fo}=\frac{a \cdot t}{l^{2}}
$$

gdzie: $a$ - dyfuzyjność cieplna, $l$ - wymiar charakterystyczny, $t$ - czas.

Definiując wymiar charakterystyczny jako stosunek objętości materiału zmiennofazowego $V$ do powierzchni wymiany ciepła $A$ :

$$
l=V / A
$$

otrzymuje się: dla kuli $l_{k}=\frac{R_{k}}{3}$, gdzie $R_{k}$ jest promieniem kuli, a dla cylindrycznego pierścienia $l_{c}=\delta$, gdzie $\delta$ stanowi grubość szczeliny pierścieniowej. Zakładając jednakową objętość kuli i pierścienia cylindrycznego, uzyskuje się zależność wymiaru charakterystycznego dla kuli w funkcji parametrów geometrycznych pierścienia:

$$
l_{k}=\sqrt[3]{\frac{D \cdot H \cdot l_{c}}{36}}
$$

gdzie: $D, H$-odpowiednio średnica zewnętrzna i wysokość rozpatrywanego pierścienia cylindrycznego.

Przyjmując przykładowo pojemnik w kształcie pierścienia cylindrycznego o wymiarach: $D=430 \mathrm{~mm}, H=500 \mathrm{~mm}, \delta=20 \mathrm{~mm}$, otrzymuje się $l_{k} \cong 49 \mathrm{~mm}$. Jak widać, w tym przypadku wymiar charakterystyczny dla kuli jest ponaddwukrotnie większy od wymiaru charakterystycznego dla pierścienia. Biorąc pod uwagę określone wymiary charakterystyczne, można na podstawie zależności (2) 
określić czas osiągnięcia tej samej temperatury w przypadku kuli $t_{k}$ oraz pierścienia cylindrycznego $t_{c}$ :

$$
t_{k}=\left(\frac{l_{k}}{l_{c}}\right)^{2} \cdot t_{c}
$$

Materiał zmiennofazowy uformowany w kształcie pierścienia cylindrycznego będzie znacznie szybciej się nagrzewał niż materiał kulisty. Czas ładowania i rozładowania zasobnika będzie zatem krótszy.

\section{Podsumowanie}

W pracy jest analizowany dwupłaszczowy zbiornik ciepłej wody użytkowej $\mathrm{z}$ dodatkową wężownicą służącą do odzysku ciepła odpadowego. Przestrzeń między płaszczami jest wypełniona materiałem PCM. Zastosowany materiał zmiennofazowy powinien być uformowany w kształcie cylindrycznego pierścienia z dodatkiem pianki metalicznej. Rozwiązanie to, ze względu na przyjętą formę geometryczną pojemnika oraz właściwości termofizyczne materiału PCM, charakteryzuje się stosunkowo krótkim czasem nagrzewania. Jego zastosowanie wiąże się więc ze skróceniem czasu ładowania i rozładowania zasobnika, a tym samym z poprawą parametrów energetycznych analizowanego wymiennika.

\section{Literatura}

[1] Aneke M., Wang M.: Energy storage technologies and real life applications - A state of the art review, Applied Energy, 179 (2016) 350-377.

[2] Chandel S.S., Agarwal T.: Review of current state of research on energy storage, toxicity, health hazards and commercialization of phase changing materials, Renewable Sustainable Energy Rev., 67 (2017) 581-596.

[3] Farid M.M., Khudhair A.M., Razack S.A.K., Al-Hallaj S.: A review on phase change energy storage: materials and applications, Energy Conversion Management, 45 (2004) 1597-1615.

[4] Agyenim F., Hewitt N., Eames P., Smyth M.: A review of materials, heat transfer and phase change problem formulation for latent heat thermal energy storage systems (LHTESS), Renewable Sustainable Energy Rev., 14 (2010) 615-628.

[5] Kenisarin M., Mahkamov K.: Solar energy storage using phase change materials, Renewable Sustainable Energy Rev., 11 (2007) 1913-1965.

[6] Sharma A., Tyagi V.V., Chen C.R., Buddhi D.: Review on thermal energy storage with phase change materials and applications, Renewable Sustainable Energy Rev., 13 (2009) 318-345.

[7] Telkes M., Raymond E.: Storing solar heat in chemicals - a report on the Dover house, Heat Vent, 46 (1949) 80-86.

[8] Schaetzle W.J.: Thermal energy storage in aquifers: design and applications, Pergamon, New York 1980. 
[9] Schmidt F.W.: Thermal energy storage and regeneration, McGraw-Hill, New York 1981.

[10] Schröder J., Gawron K.: Latent heat storage, Energy Res., 5 (1981) 103-109.

[11] Abhat A., Low temperature latent heat thermal energy storage: heat storage materials, Solar Energy, 30 (1983) 313-332.

[12] Smusz R., Wilk J., Gil P., Tychanicz-Kwiecień M., Bałon P.: Badania termofizyczne materiałów zmiennofazowych w aspekcie ich zastosowań w układach do odzysku ciepła odpadowego, ZN PRz Mechanika, 35 (2018) 67-75.

[13] Mazmana M., Cabeza M.L., Mehling H., Noguesb M., Hunay Evliya, Paksoy H.Ö.: Utilization of phase change materials in solar domestic hot water systems, Renewable Energy, 34 (2009) 1639-1643.

[14] Khot S.A., Sane N.K., Gawali B.S.: Thermal energy storage using PCM for solar domestic hot water systems: A review, J. Inst. Eng. India Ser. C, 93 (2012) 171-176.

[15] Castell A., Solé C., Medrano M., Nogués M., Cabeza L.F.: Comparison of stratification in a water tank and a PCM-water tank, J. Solar Energy Eng., 131 (2009) 024501-024501-5.

[16] Cabeza L.F., Ibanez M., Sole C., Roca J., Nogues M.: Experimentation with a water tank including a PCM module, Solar Energy Mater. Solar Cells, 90 (2006) 1273-1282 .

[17] Wilk J., Smusz R.: Initial investigations of coil heat exchanger utilizing waste heat from air conditioning system, ZN PRz Mechanika, 34 1(2017) 131-138.

[18] Smusz R.: Numerical study of thermal stratification in hot water storage tank, Progress Computational Fluid Dynamics, 17 (2017) 368-375.

\title{
APPLICATION OF THE DOUBLE-WALLED HEAT EXCHANGER WITH PCM COATING IN A WASTE HEAT UTILIZING SYSTEM
}

\begin{abstract}
S u m m a r y
The paper presents the concept of the application of phase change material PCM in the waste heat recovery system. In the proposed system a double-walled storage tank has been applied. The cylindrical gap between the inner and outer shells is filled with the PCM material. PCM changes the physical state during the process of water heating, so thermal energy is stored. The separation of PCM from domestic hot water ensures elimination of possible water pollutants. Moreover, metal chips are filled in the gap. They create a metal sceleton with spaces filled with PCM. The design improves conduction properties of the phase change material. In the paper the considered system has been described. The main design assumptions were presented. The possibilities of the application of PCM and the benefits of the proposed system have been discussed.
\end{abstract}

Keywords: phase change material, waste heat, heat accumulation

DOI: $10.7862 / \mathrm{rm} .2018 .33$

Przestano do redakcji: 7.06 .2018

Przyjęto do druku: 12.07.2018 